\title{
The Role of Surface Polysaccharide in Determining the Resistance of Serratia marcescens to Serum Killing
}

\author{
By HELEN L. JESSOP AND PETER A. LAMBERT* \\ Microbiology Research Group, Department of Pharmaceutical Sciences, Aston University, \\ Aston Triangle, Birmingham B4 7ET, UK
}

(Received 9 January 1986; revised 31 March 1986)

\begin{abstract}
Two O14:H12 strains of Serratia marcescens with different sensitivities to killing by normal pooled human serum were investigated. Complement binding, studied by measuring hydrophobicity and using rocket immunoelectrophoresis with anti-human $\mathrm{C} 3$, showed the sensitive cells ( $\mathbf{S 1 2 2 0 )}$ rapidly bound and fixed complement whereas the resistant cells (4444-60) bound less $\mathrm{C} 3 \mathrm{~b}$. The strains had identical membrane protein composition. Crossed immunoelectrophoresis suggested that in S1220 cells the polysaccharide material including LPS was less antigenic and present in smaller amounts than in 4444-60 cells. This was confirmed by examining extracted polysaccharide material chemically and by SDS-PAGE. The resistant strain had $33 \%$ more phenol-extractable polysaccharide material than the sensitive strain, possibly comprising LPS with longer $O$ antigen chain lengths, or a microcapsule of $O$ antigen polysaccharide. Extra polysaccharide material on the surface of the resistant strain prevents complement components binding and reaching the hydrophobic membrane where lytic lesions occur.
\end{abstract}

\section{INTRODUCTION}

Serratia marcescens is becoming an important opportunistic pathogen that can cause outbreaks of sepsis in special care baby units (Lewis et al., 1983) and urinary and respiratory tract infections in immunocompromised patients (Yu, 1979; Bullock et al., 1982). Serotyping is based on the $O$ (lipopolysaccharide, LPS) and $H$ (flagella) antigens, the most prevalent combination isolated clinically being O14:H12 (Pitt, 1982). K (capsular) antigens have been noted (Ewing et al., 1959; Traub et al., 1985), but await further elucidation.

The complement-mediated bactericidal effect of normal human serum plays an important role in host defence against bacterial infection. A vital step on activation of either the classical or the alternative pathway is covalent fixation of $\mathrm{C} 3 \mathrm{~b}$ to the cell surface. The early acting components of both pathways through $\mathrm{C} 3$ combine to form a cleaving enzyme which starts the sequence of reactions leading to membrane attack complex (MAC) formation, the latter being responsible for lesions in the lipid bilayers (Joiner et al., 1984). The virulence of many Gramnegative bacteria has been linked to the $\mathrm{O}$ and $\mathrm{K}$ antigens, their presence often enabling the cells to resist direct complement killing (Taylor, 1983). Outer membrane proteins (OMPs), for example the TraT protein of Escherichia coli, have also been associated with resistance (Moll et al., 1980).

In previous work we suggested that in $S$. marcescens New CDC O14:H12 the O antigen masks other antigenic sites on the cell surface and is the dominant surface exposed antigen (Jessop \& Lambert, 1985). In this paper we investigate the influence of variation in the amount of surface polysaccharide material upon the sensitivity of two $\mathrm{O} 14: \mathrm{H} 12$ strains to complement.

Abbreviations: MAC, membrane attack complex; NPHS, normal pooled human serum; OMP, outer membrane protein. 


\section{METHODS}

Organisms and growth conditions. The two $\mathrm{O} 14: \mathrm{H} 12$ serotyped strains of $S$. marcescens used were reference strain 4444-60 and a urinary tract infection isolate, S1220 (both kindly donated by Dr T. L. Pitt, PHLS, Colindale, London). Cells were grown in an orbital shaker at $37^{\circ} \mathrm{C}$ to mid-exponential phase in tryptone soy broth (TSB; Lab M) to an $\mathrm{OD}_{470}$ of 0.3 and a doubling time of $20 \mathrm{~min}$.

Serum bactericidal assays. A suspension of bacteria in saline $\left(0.6 \mathrm{ml} ; \mathrm{OD}_{470} 0.2\right)$ was added to $0.6 \mathrm{ml} \mathrm{normal}$ pooled human serum (NPHS) obtained from six healthy volunteers and the mixture was incubated at $37^{\circ} \mathrm{C}$ in a reciprocal shaking water bath. Samples $(100 \mu \mathrm{l})$ were taken at intervals, diluted with sterile saline and viable counts made according to the method of Miles \& Misra (1938).

Opsonization of bacteria. NPHS was added to cells resuspended in saline $\left(\mathrm{OD}_{470} 1.0\right)$ to give a serum concentration of $10 \%(\mathrm{v} / \mathrm{v})$. After incubation, with shaking, for $15 \mathrm{~min}$ at $37^{\circ} \mathrm{C}$ the bacteria were harvested, the supernate was retained, and the cells were washed twice in saline. NPHS, heat-inactivated at $56^{\circ} \mathrm{C}$ for $30 \mathrm{~min}$, was used in a control experiment.

Bacterial adherence to hydrocarbon. The technique developed by Rosenberg et al. (1980) was used where $100 \mu \mathrm{l}$ octane was added to $1.2 \mathrm{ml}$ normal or opsonized bacteria resuspended to $\mathrm{OD}_{470} 0.3$ in PUM buffer $\left(\mathrm{K}_{2} \mathrm{HPO}_{4} \cdot 3 \mathrm{H}_{2} \mathrm{O}, 22.2 \mathrm{~g} ; \mathrm{KH}_{2} \mathrm{PO}_{4}, 7 \cdot 26 \mathrm{~g} ;\right.$ urea, $1.8 \mathrm{~g} ; \mathrm{MgSO}_{4} .7 \mathrm{H}_{2} \mathrm{O}, 0.2 \mathrm{~g}$; distilled water to $\left.1000 \mathrm{ml}, \mathrm{pH} 7 \cdot 1\right)$. After 10 min preincubation at $25^{\circ} \mathrm{C}$, the mixture was vortex mixed for $120 \mathrm{~s}$. When separation of the layers was complete, the $\mathrm{OD}_{470}$ of the aqueous phase was measured.

Solubilization of bacteria. Opsonized or normal cells were solubilized in $4 \%(\mathrm{v} / \mathrm{v})$ Triton X-100 in $50 \mathrm{~mm}$ Tris/ $\mathrm{HCl}, \mathrm{pH} 8.6$, containing $5 \mathrm{mM}$-EDTA (Triton/EDTA) for $2 \mathrm{~h}$ at $25^{\circ} \mathrm{C}$ to give a protein concentration of $2 \mathrm{mg}$ $\mathrm{ml}^{-1}$ for rocket or $10 \mathrm{mg} \mathrm{ml} \mathrm{m}^{-1}$ for crossed immunoelectrophoresis. Unsolubilized cells were removed by centrifugation and the remaining soluble antigen extract was analysed.

Rocket immunoelectrophoresis. The method of Laurell (1966) was used where $0 \cdot 1 \%(\mathrm{v} / \mathrm{v})$ goat anti-human complement C3 (Sigma) was absorbed with $S$. marcescens cells and added to $1 \%(\mathrm{w} / \mathrm{v})$ agarose in Tris/barbiturate buffer, pH 8.6 (LKB), which was then cast onto Gel bond film (LKB).

Crossed immunoelectrophoresis (CIE). This was done as described by Weeke (1973) using $1 \%(w / v)$ agarose in Tris/barbiturate buffer cast onto Gel bond film. Antiserum was raised in rabbits to UV-killed whole cells of strain 4444-60 or strain S1220 as described by Driver \& Lambert (1984). Electrophoresis was at $10 \mathrm{~V} \mathrm{~cm}^{-1}$ for $2 \mathrm{~h}$ in the first dimension and at $2 \mathrm{~V} \mathrm{~cm}^{-1}$ for $18 \mathrm{~h}$ in the second dimension, both at $10^{\circ} \mathrm{C}$. Gels were washed, pressed and stained with Coomassie Blue. A blank intermediate gel was interposed between the first and second dimension gels to increase resolution.

In one experiment, samples of solubilized whole cells $(30-40 \mu \mathrm{l})$ were treated in various ways before CIE. They were (1) autoclaved $\left(121^{\circ} \mathrm{C}\right.$ ) for $15 \mathrm{~min}$ or (2) digested with proteinase $\mathrm{K}$ (Sigma; $10 \mu \mathrm{g}$ in $5 \mathrm{~mm}$-Tris/ $\mathrm{HCl}, \mathrm{pH} \mathrm{6.8}$ ) at $60{ }^{\circ} \mathrm{C}$ for $1 \mathrm{~h}$, or (3) oxidized with $0.1 \mathrm{M}$-sodium periodate in sodium acetate buffer (pH 4.5) at room temperature for $16 \mathrm{~h}$, excess periodate then being consumed by adding butane-2,3-diol.

Tandem CIE of solubilized whole cells with phenol-extractable polysaccharide material, $10 \mathrm{mg} \mathrm{ml}^{-1}$ (see below), was done according to Kroll (1973). Briefly, samples of solubilized whole cells and phenol-extractable material were placed in adjacent wells in the agarose, with the polysaccharide material in the well nearer the anode. After allowing the material to diffuse for $1 \mathrm{~h}$ at $20^{\circ} \mathrm{C}$ the wells were filled with cooled molten agarose and subjected to CIE.

Iodination of cells. Cells were iodinated using [ $\left.{ }^{125} \mathrm{I}\right]$ lactoperoxidase (Lambert \& Booth, 1982) and the activity of the labelled cells was measured with a $\gamma$-counter. After solubilization and CIE, autoradiographs of the CIE plates of the labelled cells were developed at room temperature for $7 \mathrm{~d}$ using Singul-XRP X-ray film (Ceaverken AB, Strängnäs, Sweden).

Extraction and chemical analysis of LPS. LPS and associated acidic exopolysaccharides produced by the strains (Brigden \& Wilkinson, 1985) were extracted from 2-litre cultures of cells by the phenol/water method of Westphal $\&$ Jann (1965). After dialysis of the material for $24 \mathrm{~h}$ against running tap water, DNAase and RNAase (10 $\mu \mathrm{g}$ of each per $\mathrm{ml}$ ) were added to digest any contaminating nucleic acid (incubated for $16 \mathrm{~h}$ at $37^{\circ} \mathrm{C}$ ). The polysaccharide material was then re-extracted, dialysed, freeze-dried and the total weight determined. The following chemical assays were done on a $10 \mathrm{mg} \mathrm{ml}^{-1}$ solution of purified material. (1) Total carbohydrate (hexose) by the phenol/sulphuric acid method (Dubois et al., 1956). (2) Total KDO (3-deoxy-D-manno-2-octulosonic acid) by a method based on that of Osborn (1963). Briefly, material was hydrolysed in sealed tubes at $100^{\circ} \mathrm{C}$ for $30 \mathrm{~min}$ and oxidized with periodate $(12 \mathrm{mM})$ at $55^{\circ} \mathrm{C}$ for $20 \mathrm{~min}$. Excess periodate was consumed with sodium arsenite and the colours generated by heating with thiobarbituric acid at $100{ }^{\circ} \mathrm{C}$ for $20 \mathrm{~min}$. (3) Total fatty acids by gas-liquid chromatography after acid hydrolysis $(6 \mathrm{M}-\mathrm{HCl})$ at $100^{\circ} \mathrm{C}$ for $4 \mathrm{~h}$ (Lambert \& Moss, 1983) with an internal standard of tridecanoic acid (Sigma).

Sodium dodecylsulphate-polyacrylamide gel electrophoresis (SDS-PAGE). The phenol-extractable material was analysed by SDS-PAGE (Lugtenberg et al., 1975) using $12 \%(\mathrm{w} / \mathrm{v})$ acrylamide gels containing $4 \mathrm{M}$-urea, and detected by silver-staining (Tsai \& Frasch, 1982). 


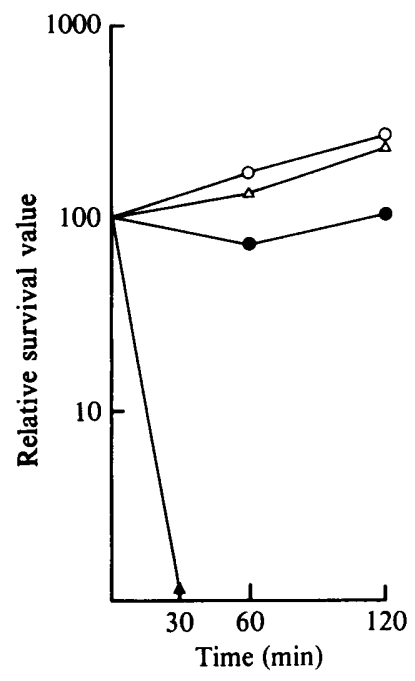

Fig. 1

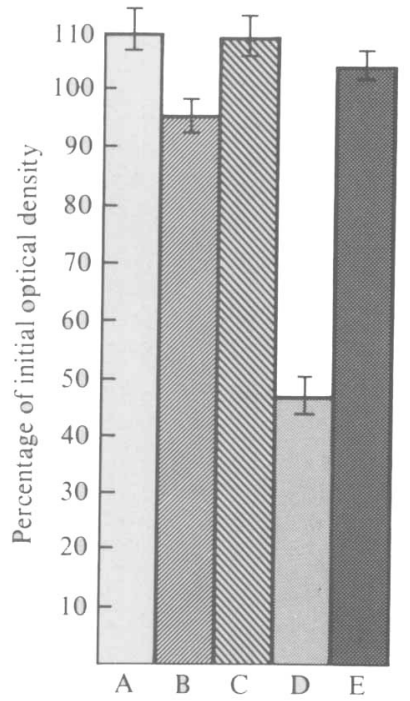

Fig. 2

Fig.1. Kinetics of killing of $S$. marcescens by normal pooled human serum (NPHS) (filled symbols) or by heat-inactivated NPHS (open symbols): $O$, strain 4444-60; $\triangle$, $\Delta$, strain S1220. The survival values indicate viable counts to time zero. Similar results were obtained in three separate experiments.

Fig. 2. Affinity of bacterial whole cells to octane. Cell suspensions $(1.2 \mathrm{ml})$ were vortex mixed with $0.1 \mathrm{ml}$ octane, the phases allowed to separate and the optical density of the aqueous phase determined. Results are expressed as a percentage of the initial optical density of the aqueous cell suspension. A, strain 4444-60; B, strain 4444-60 after contact with $10 \%$ (v/v) NPHS for $15 \mathrm{~min}$; C, strain, S1220; D, strain S1220 after contact with $10 \%$ (v/v) NPHS for $15 \mathrm{~min}$; E, as D, but heat-inactivated NPHS was used.

\section{RESULTS}

\section{Serum bactericidal assays}

The assays showed that strain S1220 is sensitive to rapid killing by complement whereas strain 4444-60, by comparison, is resistant (Fig. 1). Both strains grew in heat-inactivated NPHS. Using SDS-PAGE and the immunoblotting techniques described by Jessop \& Lambert (1985), we confirmed that the NPHS contained a low titre of antibodies to $S$. marcescens antigens, particularly the OmpA protein (data not shown).

\section{Bacterial adherence to hydrocarbon}

The sensitive cells became hydrophobic after $15 \mathrm{~min}$ incubation with $10 \%(\mathrm{v} / \mathrm{v})$ NPHS, remaining hydrophilic when heat-inactivated serum was used (Fig. 2, D and E). This suggested that fixation and opsonization of complement components to the S1220 cells was occurring. With 4444-60 cells, it appeared that there was virtually no binding (Fig. 2, A and B).

\section{Rocket immunoelectrophoresis}

Rocket immunoelectrophoresis, using goat-anti-human $\mathrm{C} 3$ antisera of whole cells solubilized after being in contact with $10 \%$ NPHS for $15 \mathrm{~min}$, showed that strain S1220 rapidly bound C3b (Fig. 3, B) whereas strain 4444-60 bound small amounts only (Fig. 3, A).Controls with bacteria solubilized after contact with heat-inactivated NPHS gave no rockets (data not shown). Analysis of the $10 \%(\mathrm{v} / \mathrm{v})$ NPHS after removal of the cells, showed that the quantity of $\mathrm{C} 3$ in the supernate after contact with strain $\mathbf{S} 1220$ increased, indicating activation of the complement pathway (Fig. 3, D), involving splitting of C3 into C3a and C3b, all of which are presumably detected by the anti-C3 serum. 


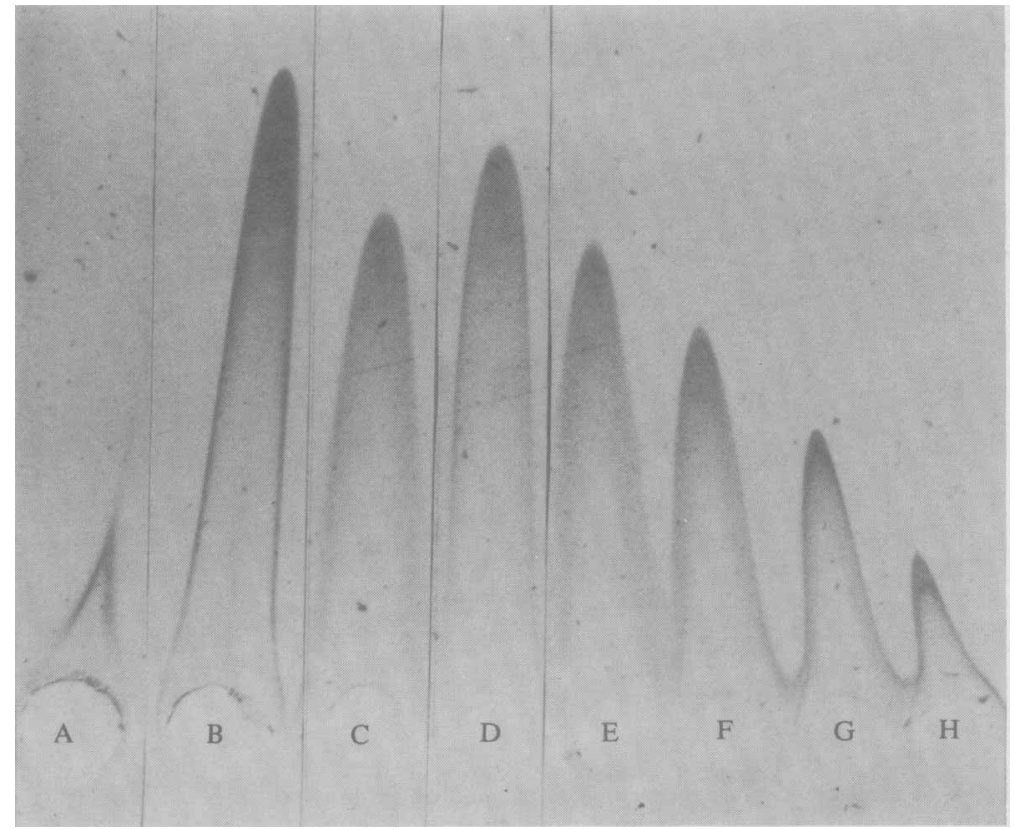

Fig. 3. Rocket immunoelectrophoresis using anti-human $\mathrm{C} 3$ antiserum of : $\mathrm{A}, \mathrm{B}$, solubilized whole cells of $S$. marcescens reacted with $10 \%$ (v/v) NPHS for $15 \mathrm{~min} ; \mathrm{C}, \mathrm{D}$, the supernate $(10 \%, \mathrm{v} / \mathrm{v})$ NPHS remaining after removal of the cells. The strains used were $4444-60$ (A, C) and S1220 (B, D). E to H are dilutions $(10 \%, 7 \cdot 5 \%, 5 \%, 2.5 \%)$ of NPHS in saline.

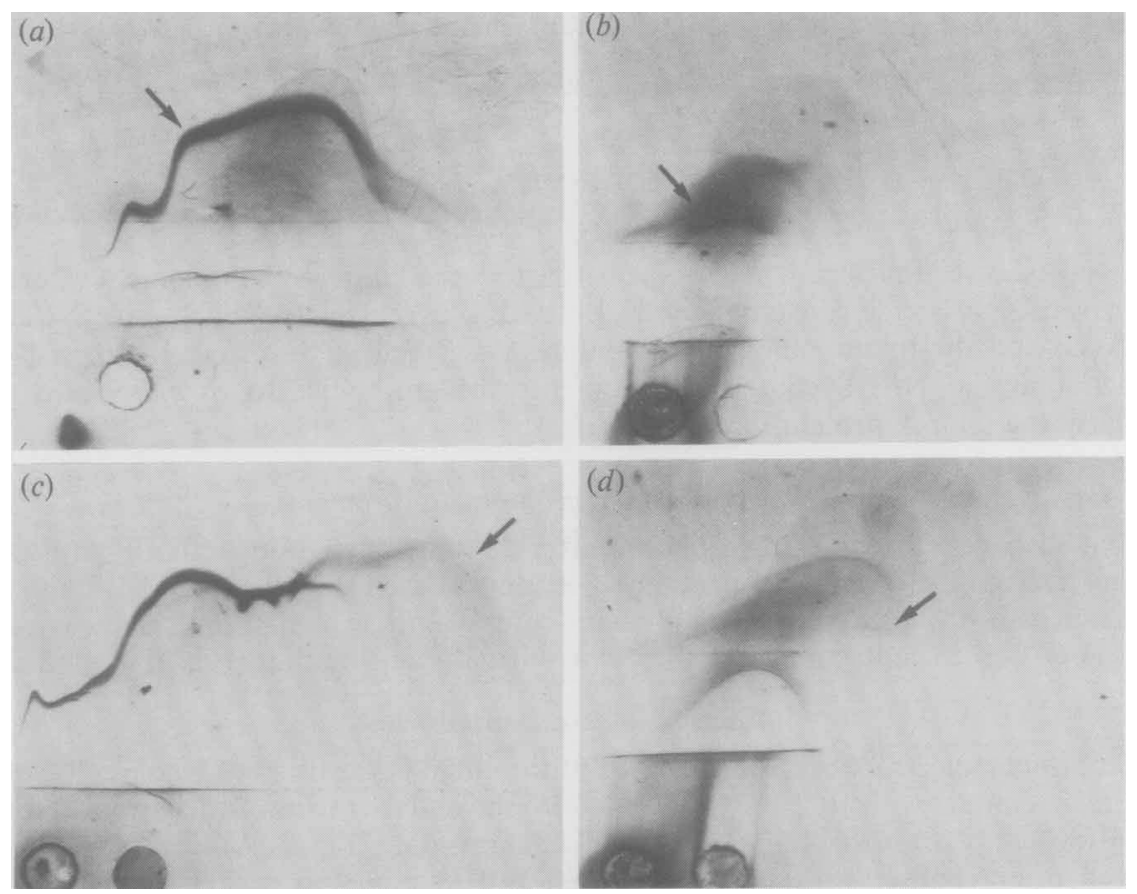

Fig. 4. CIE patterns of: (a) solubilized whole cells of strain 4444-60 $(20 \mu \mathrm{l}=200 \mu \mathrm{g}$ protein) with homologous antiserum $(200 \mu \mathrm{l})$; $(b)$ solubilized whole cells of strain $\mathrm{S} 1220(30 \mu \mathrm{l}=300 \mu \mathrm{g}$ protein) with homologous antiserum $(250 \mu \mathrm{l})$. Tandem CIE reactions of : $(c)$ as in $(a)$ with phenol-extractable material from strain 4444-60 $(20 \mu \mathrm{l}=200 \mu \mathrm{g}$ dry weight) in the second well; $(d)$ as in $(b)$ with phenol-extractable material from strain $S 1220(20 \mu \mathrm{l}=200 \mu \mathrm{g}$ dry weight $)$ in the second well. 


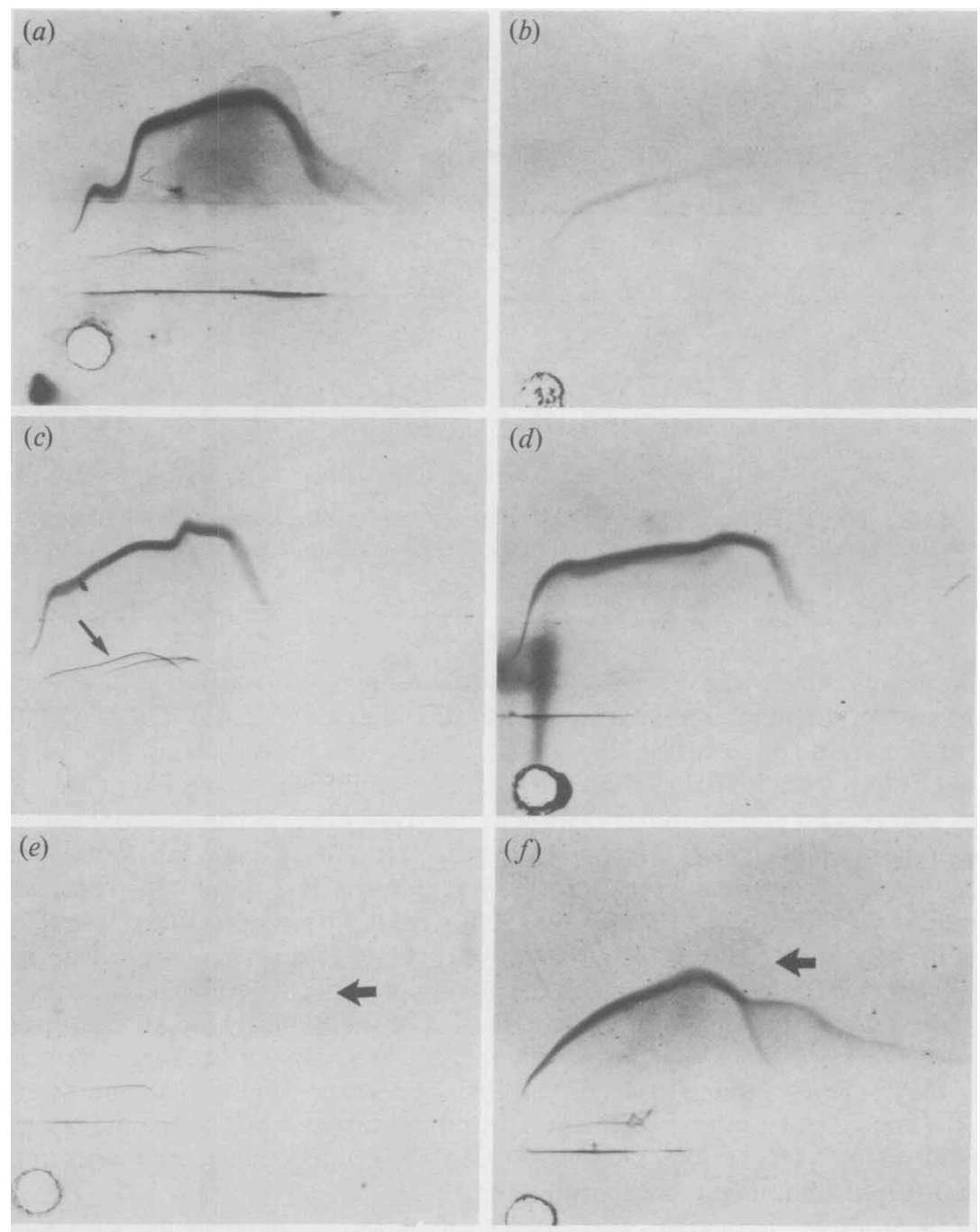

Fig. 5. CIE patterns of strain 4444-60 antiserum $(200 \mu \mathrm{l})$. (a) Solubilized whole cells of strain 4444-60 $\left(20 \mu \mathrm{l}=200 \mu \mathrm{g}\right.$ protein); (b) as (a) but extract treated first with heat $\left(121^{\circ} \mathrm{C}\right.$ for $\left.15 \mathrm{~min}\right) ;(\mathrm{c})$ as $(a)$ but extract treated first with proteinase $\mathrm{K}\left(10 \mu \mathrm{g}\right.$ in $5 \mathrm{mM}-\mathrm{Tris} / \mathrm{HCl} \mathrm{pH} 6.8,60^{\circ} \mathrm{C}$ for $\left.1 \mathrm{~h}\right) ;(d)$ as $(c)$ but without proteinase $\mathrm{K} ;(e)$ as $(a)$ but extract treated first with $0.1 \mathrm{M}$-sodium periodate in sodium acetate buffer (pH 4.5) overnight; $(f)$ as $(e)$ but without sodium periodate.

\section{SDS-PAGE of OMPS}

OMP profiles of the two strains revealed by SDS-PAGE of Sarkosyl-insoluble membranes failed to show any differences (results not published). There was no evidence, on the basis of $M_{\mathrm{r}}$ analysis, of a TraT-like protein known in Escherichia coli to be associated with resistance to serum killing (Moll et al., 1980).

\section{Iodination of cells}

[125I]Lactoperoxidase specifically labels proteins on the surface of bacteria (Lambert \& Booth, 1982); strain $4444-60$ bound 50\% less radioactive label than strain S1220. This suggested that a non-protein surface component present on the resistant cells was preventing the $\left[{ }^{125} I\right]$ lactoperoxidase reaching its binding sites. 


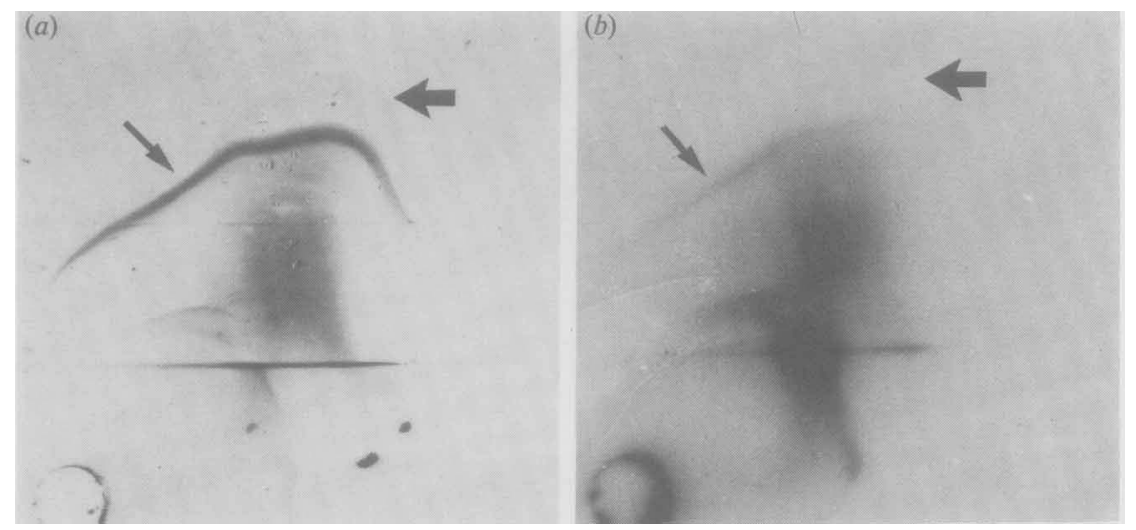

Fig. 6. CIE patterns of (a) solubilized [125I]lactoperoxidase-labelled whole cells of strain $4444-60$ $(20 \mu \mathrm{l}=200 \mu \mathrm{g}$ protein) with homologous antiserum $(200 \mu \mathrm{l})$. (b) Autoradiograph of $(a)$ developed after $7 \mathrm{~d}$.

\section{$C I E$}

Reaction of solubilized whole cells of strain 4444-60 with homologous antisera showed the presence of one dominant precipitin arc and several minor arcs (Fig. 4a). The major arc was not observed in the profile of strain S1220 with its homologous antisera (Fig. 4b).

Tandem CIE is a technique that allows two antigen samples to be applied in the same run in such a way that related precipitin peaks form as fused double peaks in the final pattern (Kroll, 1973). Running solubilized cells and isolated phenol-extractable material from strain 4444-60 suggested that the dominant arc was polysaccharide (Fig. 4c). In comparison, the polysaccharide peak in strain S1220 was a small weakly formed precipitin line (Fig. $4 d$ ).

Heating the solubilized cells of strain $4444-60\left(121^{\circ} \mathrm{C}\right.$ for $\left.15 \mathrm{~min}\right)$ destroyed all antigens apart from one that appeared to correspond with the dominant peak (Fig. $5 b$ ). The polysaccharide arc remained intact after digestion with proteinase $K$, and the fainter wide arc disappeared (Fig. $5 c$ ). The two precipitin lines that formed in the intermediate gel became very pronounced, suggesting they were not protein material, but their appearance on the CIE plates was irregular (Fig. $5 d$, the control). Periodate treatment led to the disappearance of the major antigen arc, confirming it was polysaccharide in nature (Fig. $5 e$ ). Taken together these results indicate that the major precipitin line is polysaccharide.

CIE of solubilized iodinated whole cells of strain 4444-60 (Fig. 6a) followed by autoradiography (Fig. 6 b) showed that the slower migrating portion of the polysaccharide peak was labelled and that the fainter wider arc was not. This suggested that part of the major peak was a surface protein polysaccharide complex although its antigenicity was due to the polysaccharide.

Cross-reactions by CIE of strain 4444-60 antigen with strain S1220 antiserum showed that the polysaccharide peak was indistinct (Fig. $7 a$ ) but could be located by running authentic phenolextractable material in tandem (Fig. 7c). With strain S1220 antigen and strain 4444-60 antiserum the polysaccharide peak became more defined than with homologous antiserum (Fig. $7 b, d)$.

CIE is a quantitative technique, the strength of the reaction and the area subtended by an immunoprecipitate being proportional to the antigen/antibody ratio (Weeke, 1973). All the results therefore suggest that in strain 4444-60 the polysaccharide material and LPS is more antigenic and is present in greater amounts than in strain S1220.

\section{Chemical analysis}

Analysis of the phenol-extractable material gave the following results (expressed as $\mu \mathrm{g}$ of each component in $1 \mathrm{mg}$ dry weight of cells for strains $4444-60$ and S1220 respectively $\pm \mathrm{SD}$ ): total weight extracted, $83 \pm 4.9$ and $56 \pm 3 \cdot 6$; total hexose, $36 \pm 2.8$ and $20 \pm 1.9$; total fatty acids, 


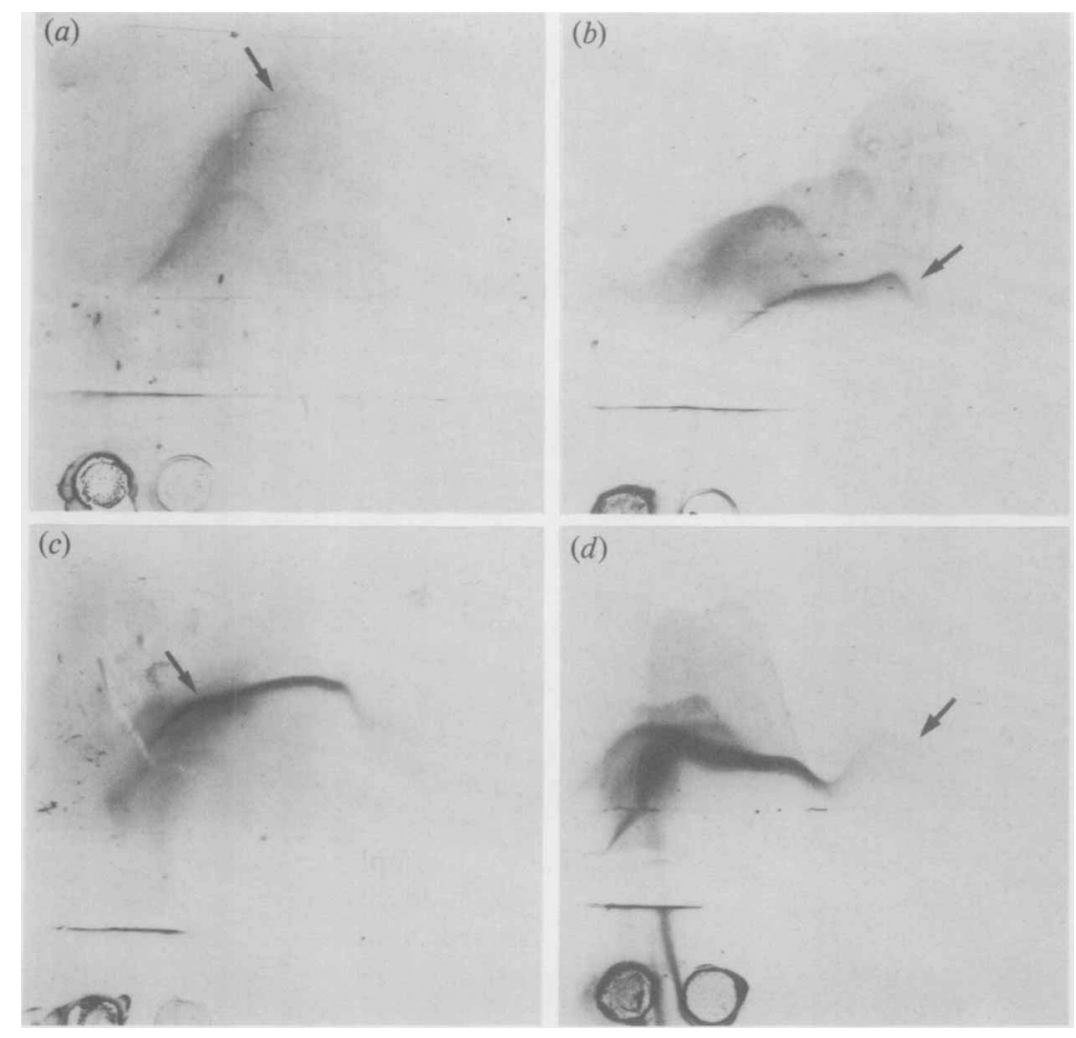

Fig. 7. CIE patterns of: (a) solubilized whole cells of strain $4444-60(20 \mu \mathrm{l}=200 \mu \mathrm{g}$ protein $)$ with strain S1220 antiserum $(250 \mu \mathrm{l}) ;(b)$ solubilized whole cells of strain $\mathrm{S} 1220(30 \mu \mathrm{l}=300 \mu \mathrm{g}$ protein) with strain 4444-60 antiserum $(200 \mu \mathrm{l})$. Tandem CIE reactions of : $(c)$ as $(a)$ with phenol-extractable material from strain 4444-60 $(20 \mu \mathrm{l}=200 \mu \mathrm{g}$ dry weight) in the second well; $(d)$ as (b) with phenol-extractable material from strain $\mathrm{S} 1220(20 \mu \mathrm{l}=200 \mu \mathrm{g}$ dry weight $)$ in the second well.

$1.8 \pm 0.1$ and $1.7 \pm 0 \cdot 1$; total KDO, $6.7 \pm 0.35$ and $0.84 \pm 0.04$; ratio hexose : fatty acids, $20: 1$ and $12: 1$. The serum resistant strain had $33 \%$ more phenol-extractable material than the sensitive one. The KDO measurements for strain $4444-60$ are probably influenced by the presence of a related sugar which gives a positive response with the periodate/thiobarbituric assay (Brigden \& Wilkinson, 1983). We assume that this component is not present in LPS from strain S1220. We therefore used fatty acid analysis (after acid hydrolysis to release amidelinked fatty acids) as an independent measure of LPS. The nature and relative proportions of fatty acids in each LPS were identical, viz. : laurate, $5 \%$, myristate, $27 \%$; 3-hydroxymyristate, $60 \%$; unknown, $8 \%$. These values are close to those reported by Alaupovic et al. (1966), although their proportion of $\beta$-hydroxymyristic acid was lower, due to milder conditions of acid hydrolysis. The ratio of hexose to fatty acids suggested that, in phenol-extractable material from strain 4444-60, the average sugar chain length of the LPS is longer than in strain S1220, or a polysaccharide microcapsule is present.

\section{$S D S-P A G E$ of polysaccharides}

Identical amounts of phenol-extractable material were loaded to each track in Fig. 8. It appears that strain 4444-60 contained a proportion of material which migrated slowly, was not resolved into the familiar LPS ladder pattern and is thought to be molecules with long $\mathrm{O}$ antigen chains (Peterson \& McGroarty, 1985). Strain S1220 contained far less of this material but the ladder pattern was more pronounced near the fast migrating lipid A region (probably representing rougher LPS). Attempts to resolve the slow migrating material into discrete bands 
A

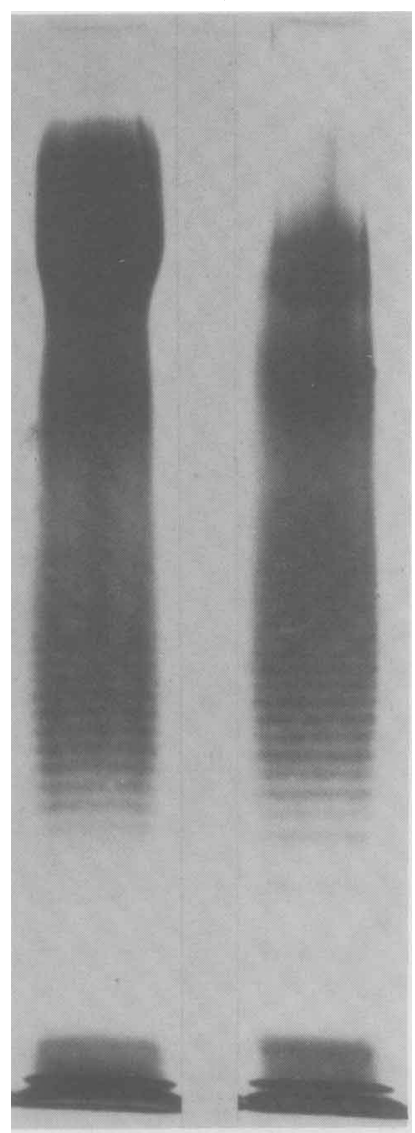

Fig. 8. Silver-stained phenol-extractable material of $S$. marcescens after SDS-PAGE from (A) strain 4444-60 (50 $\mu \mathrm{g})$ and (B) strain S1220 $(50 \mu \mathrm{g})$. Similar patterns were produced on three separate occasions.

by increasing the SDS concentration in the gel were unsuccessful (Peterson \& McGroarty, 1985). Usually, capsular polysaccharides can be separated from LPS by ultracentrifugation (Sutherland \& Wilkinson, 1971). On subjecting samples of phenol-extractable material to ultracentrifugation, a characteristic ladder pattern was obtained from both the supernate (monomeric LPS) and pellet fractions on SDS-PAGE (results not shown). We were therefore unable to distinguish capsular material in the supernate.

\section{DISCUSSION}

Analysis of two O14:H12 strains of $S$. marcescens with different sensitivities to serum killing showed that the sensitive strain rapidly bound large quantities of $\mathrm{C} 3$ to its cells, a trend found by other workers in different bacteria (Taylor \& Kroll, 1985; Engels et al., 1985). C3b bound to early acting complement components initiates the cascade responsible for MAC formation and direct cell death (Joiner et al., 1984). The attached molecules also increase the hydrophobicity of the cells, making them more sensitive to phagocytosis (Ofek \& Beachey, 1980), and C3b bound on its own opsonizes the cells, C3b receptors being found on phagocytic cells (Joiner et al., 1984).

The reasons for the differences in sensitivity could not be attributed to alterations in the OMPs. No evidence for a TraT protein was found, confirming the results of other workers (Montenegro et al., 1985).

Goldman et al. (1984) showed that the quantity of LPS covering the cells is important in determining serum sensitivity of E. coli O111B4. A mutant with $50 \%$ more LPS and an increased coverage of lipid $\mathrm{A}$ core with $\mathrm{O}$ antigen was more resistant to complement killing than its parent, 
due to restricted access of the MAC to hydrophobic membrane sites. CIE and chemical analysis showed that the serum-resistant $S$. marcescens $4444-60$ had $33 \%$ more polysaccharide material than the serum-sensitive strain S1220. SDS-PAGE suggested that strain 4444-60 contains more high $M_{\mathrm{r}}$ LPS, presumably as longer $\mathrm{O}$ antigen chains. The increased LPS content and $\mathrm{O}$ antigen chain length might direct complement components to sites further from the cell surface, preventing them reaching the hydrophobic domains and making the cells resistant to killing. By contrast, in strain S1220 the C3b and MAC can reach the outer membrane.

Little is known about the capsular antigens of $S$. marcescens, although Traub et al. (1985) isolated $\mathrm{K}$ antigen extracts from four strains. $S$. marcescens produces a complex range of surface carbohydrates and Brigden \& Wilkinson (1985) suggested that strain 4444-60 may have a microcapsule associated with its LPS. The increase in phenol-extractable material and the hexose : fatty acid ratio in strain 4444-60 compared to strain $S 1220$ could reflect the presence of such an acidic glucomannan. The polymer might run on SDS-PAGE as slowly migrating material and would be immunologically indistinguishable from the LPS on CIE. However, we could not separate any such microcapsular material from the phenol-extractable material on ultracentrifugation, even in the presence of magnesium chloride. Goldman et al. (1984) found the possession of an $\mathrm{O}$ antigen capsule in E. coli O111B4 did not affect serum sensitivity, the quantity of LPS being more important. Strain 4444-60 contains additional surface polysaccharide material compared to strain $\mathrm{S} 1220$, which restricts access of complement components to the hydrophobic membrane. We cannot conclude whether this material is in the form of more LPS with longer $O$ antigen chains, a microcapsule, or a combination of both.

Traub et al. (1985) showed that capsular polysaccharides and LPS from a range of $S$. marcescens serotypes separately afford protection against homologous strains in mice. Therefore we need to have further information both on their antigenicity and on their role in protecting the cells from serum killing.

We are grateful to Dr S. G. Wilkinson for helpful discussion.

\section{REFERENCES}

Alaupovic, P., Olson, A. C. \& Tsang, J. (1966). Studies on the characterization of lipopolysaccharides from two strains of Serratia marcescens. Annals of the New York Academy of Sciences 133, 546-565.

Brigden, C. J. \& Wilkinson, S. G. (1983). Lipopolysaccharide from the 014 type strain of Serratia marcescens: structural studies of a polymeric fraction. Carbohydrate Research 115, 183-190.

Brigden, C. J. \& Wilkinson, S. G. (1985). Structural studies of acidic glucomannans from strains of Serratia marcescens $\mathrm{O} 14$ and $\mathrm{O6}$. Carbohydrate Research 138, 267-276.

Bullock, D. W., BidWell, J. L., ReEves, D. S., White, L. O., Turner, A., Speller, D. C. E. \& WILKINSON, P. J. (1982). Outbreaks of hospital infection in southwest England caused by gentamicin-resistant Serratia marcescens. Journal of Hospital Infection 3, 263-273.

DRIVER, K. \& LAMBERT, P. A. (1984). Surface antigens of Proteus mirabilis revealed by electroblotting from sodium dodecylsulphate-polyacrylamide gels. Microbios 40, 87-98.

Dubois, M., Gilles, K. A., Hamilton, J. K., Rebers, P. A. \& SMITH, F. (1956). Colorimetric method for determination of sugars and related substances. Analytical Chemistry 28, 350-356.

ENGEls, W., ENDERT, J., Kamps, M. A. F. \& VAN BOVEN, C. P. A. (1985). Role of lipopolysaccharide in opsonization and phagocytosis of Pseudomonas aeruginosa. Infection and Immunity 49, 182-189.
Ewing, W. H., Davis, B. R. \& Reavis, R. W. (1959). Studies on the Serratia Group. Atlanta, Georgia: Center for Disease Control.

Goldman, R. C., JoIner, K. \& Leive, L. (1984). Serum-resistant mutants of Escherichia coli O111 contain increased lipopolysaccharide, lack an $\mathrm{O}$ antigen-containing capsule, and cover more of their lipid A core with $\mathrm{O}$ antigen. Journal of Bacteriology 159, 877-882.

JESSOP, H. L. \& LAMBERT, P. A. (1985). Immunochemical characterization of the outer membrane complex of Serratia marcescens and identification of the antigens accessible to antibodies on the cell surface. Journal of General Microbiology 131, 2343-2348.

JoIner, K. A., Brown, E. J. \& Frank, M. M. (1984). Complement and bacteria: chemistry and biology in host defence. Annual Review of Immunology 3, 461491.

KROLL, J. (1973). Tandem crossed immunoelectrophoresis. Scandinavian Journal of Immunology 2, supplement 1, 57-59.

LAMBert, M. A. \& Moss, C. W. (1983). Comparison of the effects of acid and base hydrolyses on hydroxy and cyclopropane fatty acids in bacteria. Journal of Clinical Microbiology 18, 1370-1377.

LAMBERT, P. A. \& BOOTH, B. R. (1982). Exposure of outer membrane proteins on the surface of Pseudomonas aeruginosa $\mathrm{PAO1}$ revealed by labelling with [125I]lactoperoxidase. FEMS Microbiology Letters 14, 43-45. 
LAURELl, C. B. (1966). Quantitative estimation of proteins by electrophoresis in agarose gel containing antibodies. Analytical Biochemistry 15, 45-52.

Lewis, D. A., Hawkey, P. M., WatTS, J. A., SPeller, D. C. E., Primavesi, R. J., Fleming, P. J. \& Pitt, T. L. (1983). Infection with netilmicin resistant Serratia marcescens in a special care baby unit. British Medical Journal 287, 1701-1705.

Lugtenberg, B., Meijers, J., Peters, R., VAN Der HoEK, P. \& VAN ALPHEN, L. (1975). Electrophoretic resolution of the major outer membrane protein of E. coli K12 into four bands. FEBS Letters 58, 254 258.

Miles, A. A. \& MisRA, S. S. (1938). The estimation of the bactericidal power of blood. Journal of Hygiene 38, 732-748.

Moll, A., Manning, P. A. \& Timmis, K. N. (1980). Plasmid-determined resistance to serum bactericidal activity: a major outer membrane protein, the traT gene product, is responsible for plasmid-specified serum resistance in Escherichia coli. Infection and Immunity 28, 359-367.

Montenegro, M. A., Bitter-Suermann, D., Timmis, J. K., Aguero, M. E., Cabello, F. C., Sanyal, S. C. \& Timmis, K. N. (1985). traT Gene sequences, serum resistance and pathogenicity-related factors in clinical isolates of Escherichia coli and other Gramnegative bacteria. Journal of General Microbiology 131, 1511-1521.

OFEK, I. \& BEACHEY, E. H. (1980). General concepts and principles of bacterial adherence in animals and man. In Bacterial Adherence. Receptors and Recognition, series B, volume 6, pp. 1-29. Edited by E. H. Beachey. London: Chapman and Hall.

OsBORN, M. J. (1963). Studies on the Gram-negative cell wall. I. Evidence for the role of 2-keto-3deoxyoctonate in the LPS of Salmonella typhimurium. Proceedings of the National Academy of Sciences of the United States of America 50, 499-506.
Peterson, A. A. \& McGroarty, E. J. (1985). Highmolecular weight components in lipopolysaccharides of Salmonella typhimurium, Salmonella minnesota and Escherichia coli. Journal of Bacteriology 162, 738745.

PITT, T. L. (1982). State of the art: typing of Serratia marcescens. Journal of Hospital Infection 3, 9-14.

Rosenberg, M., GutnigK, D. \& RosenberG, E. (1980). Adherence of bacteria to hydrocarbons: a simple method for measuring cell-surface hydrophobicity. FEMS Microbiology Letters 3, 29-33.

Sutherland, I. W. \& Wilkinson, J. F. (1971). Chemical extraction methods of microbial cells. Methods in Microbiology 5B, 345-383.

TAYLOR, P. W. (1983). Bactericidal and bacteriolytic activity of serum against Gram-negative bacteria. Microbiology Reviews 47, 46-83.

TAYLOR, P. W. \& KROLL, H. P. (1985). Effect of lethal doses of complement on the functional integrity of target enterobacteria. Current Topics in Microbiology and Immunology 121, 135-158.

Traub, W. H., SPOHR, M. \& Bauer, D. (1985). Active immunization of NMRI mice against Serratia marcescens. Zentralblatt für Bakteriologie, Mikrobiologie und Hygiene (Abteilung I, Originale A) 259, 410425.

Tsai, C. M. \& Frasch, C. E. (1982). A sensitive silver stain for detecting lipopolysaccharides in polyacrylamide gels. Analytical Biochemistry 119, 115-119.

WEEKE, B. (1973). Crossed immunoelectrophoresis. Scandinavian Journal of Immunology 22, supplement 1, 47-56.

WestPhal, O. \& JANN, K. (1965). Bacterial lipopolysaccharides: extraction with phenol/water and further applications of the procedure. Methods in Carbohydrate Chemistry 5, 83-91.

YU, V. L. (1979). Serratia marcescens - historical perspective and clinical review. New. England Journal of Medicine 300, 887-891. 